This article is licensed under the Creative Commons Attribution-NonCommercial 4.0 International License (CC BY-NC) (http://www.karger.com/Services/OpenAccessLicense). Usage and distribution for commercial purposes requires written permission.

\title{
Metachronous Sigmoid Carcinoma and Mantle Cell Lymphoma in Intestines
}

\author{
Qiao $\mathrm{Yu}^{\mathrm{a}}$ Qiu-Yan Liu ${ }^{\mathrm{b}}$ Dan-Ming $\mathrm{Wei}^{\mathrm{a}}$ Dian-Zhong Luo ${ }^{\mathrm{a}}$
}

aDepartment of Pathology, the First Affiliated Hospital of Guangxi Medical University, Nanning, China; ${ }^{b}$ Department of Anesthesiology, the Second Affiliated Hospital of Guangxi Medical University, Nanning, China

\section{Keywords}

Multiple primary malignant tumors · Mantle cell lymphoma $\cdot$ Sigmoid carcinoma

\begin{abstract}
It is rare that colon carcinoma and mantle cell lymphoma $(\mathrm{MCL})$ occur one after another in intestines. We found two malignancies of sigmoid carcinoma and $\mathrm{MCL}$ in a single patient, who had initially been diagnosed with sigmoid carcinoma and treated with radical resection in our hospital. Good postoperative recovery was reported without recurrence signs, which lasted for 7 years and 5 months until polyps of sigmoid colon were found by colonoscopy. Biopsy and immunohistochemistry revealed $\mathrm{MCL}$, but the patient refused treatment. One year later, $\mathrm{MCL}$ was diagnosed again in the transverse colon. The patient is currently under observation and has not received treatment for MCL.

(C) 2019 The Author(s)

Published by S. Karger AG, Basel
\end{abstract}




\section{Case Reports in Gastroenterology}

Case Rep Gastroenterol 2019;13:17-24

DOI: $10.1159 / 00049578$

(c) 2019 The Author(s). Published by S. Karger AG, Basel www.karger.com/crg

Yu et al.: Metachronous Sigmoid Carcinoma and Mantle Cell Lymphoma in Intestines

\section{Introduction}

Multiple primary malignant tumors (MPMTs), first proposed by Billroth in 1889, refers to 2 or more independent primary malignant tumors occurring simultaneously or successively in one or more organs of the same individual [1]. Each tumor must be malignant and have its distinct pathological morphology except for metastasis or recurrence, which are the diagnostic criteria of MPMTs put forward by Warren and Gates [2]. MPMTs can be divided into synchronous carcinoma (SC) and metachronous carcinoma (MC) depending on whether or not the tumors occur simultaneously. SC occurred within 6 months while the occurrence of MC must be spaced more than half a year apart [3]. There was a higher incidence in patients with MC than it in patients with SC [4]. The most common site of MPMTs was the same organ, followed by paired organs or the organs of the identical system [5].

One clinical work manifested that the prevalence of MPMTs was 1.09\% $(167$ of 15,321) [6]. However, most MPMTs are double primary tumors and the occurrence rate of triple tumors and quadruple tumors is less common than double primary malignancy. Among the malignant tumors, only $0.5 \%$ were triple tumors and $0.3 \%$ were quadruple tumors [7]. The occurrence of MPMTs may be caused by some factors such as genetic predisposing factor, hypoimmunity, radiotherapy and chemotherapy, environmental factors, and unhealthy lifestyles. An MPMTs patient who suffered from ovarian and breast cancer was found to have copy-neutral loss of heterozygosity of PALB2 by conducting whole-genome sequencing [8]. A combination of genetic susceptibility and environmental exposure to asbestos and ultraviolet radiation could lead to MPMTs in a family [9]. Radiotherapy and chemotherapy may be the cause of gastric adenocarcinoma after treatment of lymphoma [10].

Mantle cell lymphoma (MCL) and sigmoid colon cancer are two different malignancies. MCL is a type of B-cell non-Hodgkin lymphoma, and most MCL patients were middle-aged and old-aged males with a median age of 61 years [11]. The most common site of involvement other than lymph nodes is the gastrointestinal tract [11]. MCL has the invasive biological characteristics of medium and high malignant lymphoma, and its response to treatment is similar to that of indolent lymphoma, so it is considered as an incurable disease [12]. Researchers found patients over 60 years old or with spleen involvement who had a poor prognosis [11]. Besides, in terms of immunohistochemical results, if the overlapping degree between the reticular structure of the follicular dendritic cell and tumor cells was less than $90 \%$ or the Ki67 -positive index was greater than $40 \%$, the patient's prognosis was also poor [11]. Colon cancer, one of the most common malignancies and sigmoid colon cancer being the most common, ranks third in the estimated cancer incidence and mortality rate in the United States in 2018 [13].

It is rare to have colon carcinoma and MCL of the colon at the same time, and to our knowledge, only a few cases have been reported [14-16]. However, there have been no reports of cases where MCL of the colon occurred years after colon cancer resection without recurrence of colon cancer. In this study, we report the case of a male patient (69 years old) who suffered from MCL of the intestines 7 years after having had a radical resection of sigmoid carcinoma, aiming to deepen our understanding of this kind of disease and preliminarily explore the relationship between MCL and sigmoid colon cancer. 


\section{Case Reports in Gastroenterology}

Case Rep Gastroenterol 2019:13:17-24

DOI: 10.1159/00049578

(C) 2019 The Author(s). Published by S. Karger AG, Basel www.karger.com/crg

Yu et al.: Metachronous Sigmoid Carcinoma and Mantle Cell Lymphoma in Intestines

\section{Case Report}

A male patient, aged 69 years and a native of the Guangdong province, had had a history of hypertension for more than 10 years and long-term oral administration of amlodipine for blood pressure control. He also had a history of chronic cholecystitis, gallstone, and hyperplasia of the prostate. His father had lung cancer and bowel cancer and his mother died of coronary heart disease. He denied a habit of smoking and drinking.

The patient underwent radical resection of a sigmoid carcinoma in our hospital on February 10,2010 . A polypoid mass and a cauliflower-like mass were found on the gross pathological examination, and infiltration into the submucosa was observed with the naked eye. Microscopic examination of the masses showed sigmoid colon tubular adenocarcinoma grade II infiltrating into the deep muscle layer (Fig. 1). Six chemotherapy treatment courses of CF+ 5 -FU + oxaliplatin were administered after conducting surgery. During this period, the patient felt mild sensory abnormalities in the extremities, without abdominal pain, distension, nausea, vomiting, cold, fever, cough, and expectoration. Periodic reexamination showed no recurrence of the tumor.

On July 26, 2017, a syncope occurred after some activity as a result of fever and lack of food intake. The patient fell over and the occipitalia hit the ground, being unconscious for about $3 \mathrm{~min}$, of which he recovered. CT examination suggested brain atrophy with no bleeding. At reexamination of the electron colonoscopy on August 1,2017, multiple polypoid eminences of sigmoid colon were found with a high possibility of inflammatory hyperplasia (Fig. 2). Microscopic examination of the polyps showed a large number of hyperplastic lymphoid cells under the mucosa with a single shape (Fig. 3a, b). On examination of immunohistochemistry (IHC), hyperplastic lymphocytes were positive for CD5 (Fig. 3c), cyclin D1 (Fig. 3d), CD20 (Fig. 3e), CD79 $\alpha$, Bcl-2, CD43, and Ki-67 (40\%) (Fig. 3f), and negative for CD10 (Fig. 3g) and CD23 (Fig. 3h). In combination with morphology and IHC, the patient was diagnosed with MCL. Bone marrow cytology and bone marrow pathology showed no involvement of the lymphoma. Special stain for Fe, PAS, and Ag showed to be negative. PET/CT examination indicated no increased glucose metabolism. The blood routine tests remained normal: WBC, $7.88 \times 10^{9} / \mathrm{L}$; RBC, $4.23 \times 10^{12} / \mathrm{L} ; \mathrm{HGB}, 137 \mathrm{~g} / \mathrm{L}$; PLT, $132 \times 10^{9} / \mathrm{L}$. Transverse colonic polyps were found during a repeat colonoscopy review on July 26,2018 . IHC results were similar to those of last year, and the diagnosis of MCL was rendered again.

\section{Discussion}

In this case, the pathological diagnosis confirmed that two types of malignant tumors, sigmoid carcinoma and MCL, developed at different times. The time interval was more than 6 months, which was consistent with the diagnosis of MPMTs. Although sigmoid colon cancer is common and mantle cell tumors of the intestinal tract are not rare, it is rare for the same person to have both. Six similar cases reported in the literature and our case are summarized and listed in Table 1 [14-18]. Among them, 4 cases were SC and the remaining 3 cases were MC. No cases of MCL occurring before bowel cancer were found. All cases occurred in middle-aged or old-aged males, with an average age of 73.6 years (54-83 years old) and a median age of 75 years. 


\section{Case Reports in Gastroenterology}

Case Rep Gastroenterol 2019:13:17-24

(c) 2019 The Author(s). Published by S. Karger AG, Base www.karger.com/crg

Yu et al.: Metachronous Sigmoid Carcinoma and Mantle Cell Lymphoma in Intestines

The etiology and mechanism of MPMTs have not been defined yet, which may be related to genetic susceptibility, genetic factors, radiotherapy and chemotherapy, living environment, and lifestyle $[19,20]$. Patients with MPMTs are more likely to carry harmful mutations than those with a single primary cancer [21]. The direct relative of the patient in this case was also an MPMTs patient with lung cancer and bowel cancer. Hence, the patient has two types of tumors that may be genetic. He had also received radiotherapy and chemotherapy before suffering from MCL, which may be the cause of MCL.

On account of the lower rates of MPMTs and the diversity of clinical features, MPMTs should be distinguished from metastatic cancer [6]. Tumor cells invade lymphatic vessels, blood vessels, or other pathways and transfer from the primary site to another site for further growth, forming the same type of tumor as the primary tumor, which is the process of metastasis. Lymphoma was misdiagnosed as metastatic gingival carcinoma because the clinical presentation of maxillofacial lymphoma is very similar to that of squamous cell carcinoma [22]. Of course, metastatic cancer can camouflage and also present different morphology from the original site of the tumor, so that it is easy to be misdiagnosed as MPMTs. It was reported that Hodgkin lymphoma involving the tonsils has been misdiagnosed as tonsil cancer [23].

Because of different pathological types of tumors and time intervals for diagnosis, MPMTs have different treatment principles. For SC, life-threatening tumors or tumors with a poor prognosis should be treated first, while for MC, one tumor can be treated at a time [24]. In this case, the patient was diagnosed with two types of tumors with a long time interval, and sigmoid carcinoma was resected without recurrence. Although the MCL of the intestinal tract he suffered from had no other systemic involvement, the tumor proliferation index Ki-67 was high. He was supposed to be hospitalized but kept waiting.

The relationship between colorectal cancer and MCL of the intestinal tract is unclear. After searching the literature, we found they either occur at the same time or MCL appears after intestinal cancer. Whether intestinal cancer is a cause of lymphoma is still unknown. Their occurrence may be accidental. MPMTs are easy to miss, leading to delayed or incorrect treatment, so early diagnosis is important. Their pathogenesis needs further study.

\section{Statement of Ethics}

The authors have no ethical conflicts to disclose.

\section{Disclosure Statement}

The authors declare no conflicts of interest.

\section{Author Contributions}

Q.Y. was responsible for the acquisition, analysis and interpretation of data for the work and drafting the paper. Q.-Y.L. participated in writing and revising the paper. D.-M.W. and 
D.-Z.L. were both in charge of the design of the work, correcting the draft, final approval of the version to be published, and agreement to be accountable for all aspects of the work.

\section{References}

1 Billroth T. [General surgical pathology and therapy. Guidance for students and physicians. Lecture]. Khirurgiia (Mosk). 1991 Oct;(10):136-43.

2 Warren S, Gates O. Multiple malignant tumors. A survey of the literature and statistical study. Am J Cancer. 1932;16:1358-414.

3 Testori A, Cioffi U, De Simone M, Bini F, Vaghi A, Lemos AA, et al. Multiple primary synchronous malignant tumors. BMC Res Notes. 2015 Nov;8(1):730.

4 Komiyama S, Nishio E, Ichikawa R, Miyamura H, Kawamura K, Komiyama M, et al. Asymptomatic synchronous quintuple primary cancers. Gynecol Obstet Invest. 2012;74(4):324-8.

5 Cozzi L, Fogliata A, Thompson S, Franzese C, Franceschini D, de Rose F, et al. Critical Appraisal of the Treatment Planning Performance of Volumetric Modulated Arc Therapy by Means of a Dual Layer Stacked Multileaf Collimator for Head and Neck, Breast, and Prostate. Technol Cancer Res Treat. 2018 Jan 1;17:1533033818803882.

6 Zhai C, Cai Y, Lou F, Liu Z, Xie J, Zhou X, et al. Multiple Primary Malignant Tumors - A Clinical Analysis of 15,321 Patients with Malignancies at a Single Center in China. J Cancer. 2018 Jul;9(16):2795-801.

7 Németh Z, Czigner J, Iván L, Ujpál M, Barabás J, Szabó G. Quadruple cancer, including triple cancers in the head and neck region. Neoplasma. 2002;49(6):412-4.

8 Schrader KA, Stratton KL, Murali R, Laitman Y, Cavallone L, Offit L, et al. Genome Sequencing of Multiple Primary Tumors Reveals a Novel PALB2 Variant. J Clin Oncol. 2016 Mar;34(8):e61-7.

9 Cheung M, Kadariya Y, Talarchek J, Pei J, Ohar JA, Kayaleh OR, et al. Germline BAP1 mutation in a family with high incidence of multiple primary cancers and a potential gene-environment interaction. Cancer Lett. 2015 Dec;369(2):261-5.

10 Brumback RA, Gerber JE, Hicks DG, Strauchen JA. Adenocarcinoma of the stomach following irradiation and chemotherapy for lymphoma in young patients. Cancer. 1984 Sep;54(6):994-8.

11 Hou WH, Wei P, Xie JL, Zheng YY, Zhang YL, Zhou XG: [Clinicopathologic features and prognosis of mantle cell lymphoma: an analysis of 349 cases]. Zhonghua Bing Li Xue Za Zhi. 2018;47:417-22.

12 Cohen JB, Zain JM, Kahl BS. Current Approaches to Mantle Cell Lymphoma: Diagnosis, Prognosis, and Therapies. Am Soc Clin Oncol Educ Book. 2017;37:512-25.

13 Siegel RL, Miller KD, Jemal A. Cancer statistics, 2018. CA Cancer J Clin. 2018 Jan;68(1):7-30.

14 Kanehira K, Braylan RC, Lauwers GY. Early phase of intestinal mantle cell lymphoma: a report of two cases associated with advanced colonic adenocarcinoma. Mod Pathol. 2001;14:811-7.

15 Padmanabhan V, Trainer TD. Synchronous adenocarcinoma and mantle cell lymphoma of the colon. Arch Pathol Lab Med. 2003 Feb;127(2):E64-6.

16 Handra-Luca A. Diagnostic challenges of composite colorectal tumors of adenoma-mantle cell lymphoma type. Ann Diagn Pathol. 2013 Dec;17(6):544-6.

17 Sztarkier I, Levy I, Walfisch S, Delgado J, Benharroch D. Mantle cell lymphoma in a tubular adenoma: unusual presentation with synchronous colonic carcinoma. Ann Diagn Pathol. 2009 Feb;13(1):47-9.

18 Liao MT, Cheng MF, Chang WC, Wu YC, Lee HS, Tsai SH. Duodenal mantle cell lymphoma in a patient with advanced sigmoid adenocarcinoma. South Med J. 2009 Apr;102(4):429-31.

19 Liu J, Wei H, Zhu K, Lai L, Han X, Yang Y. Male breast cancer and mantle cell lymphoma in a single patient: A case report and literature review. Medicine (Baltimore). 2017 Dec;96(48):e8911.

20 Hu NC, Hsieh SC, Chen TJ, Chang JY. Multiple primary malignancies including colon, stomach, lung, breast, and liver cancer: a case report and literature review. Chin Med J (Engl). 2009 Dec;122(24):3091-3.

21 Chan GH, Ong PY, Low JJ, Kong HL, Ow SG, Tan DS, et al. Clinical genetic testing outcome with multi-gene panel in Asian patients with multiple primary cancers. Oncotarget. 2018 Jul;9(55):30649-60.

22 Zhou W, Huang X, Han J, Wang Z: [Concurrent nodal and extranodal lymphoma misdiagnosed as metastatic gingival carcinoma: A case report]. Zhong Nan Da Xue Xue Bao Yi Xue Ban. 2018;43:337-40.

23 Qin Y, Lu L, Lu Y, Yang K. Hodgkin lymphoma involving the tonsil misdiagnosed as tonsillar carcinoma: A case report and review of the literature. Medicine (Baltimore). 2018 Feb;97(7):e9761.

24 Feng Y, Zhong M, Zeng S, Xiao D, Liu Y. Metachronous triple primary neoplasms with primary prostate cancer, lung cancer, and colon cancer: A case report. Medicine (Baltimore). 2018 Jun;97(26):e11332. 


\section{Case Reports in Gastroenterology}

\begin{tabular}{l|l}
\hline Case Rep Gastroenterol 2019;13:17-24 \\
\hline DOI: 10.1159/000495781 & $\begin{array}{l}\text { (c) 2019 The Author(s). Published by S. Karger AG, Basel } \\
\text { www.karger.com/crg }\end{array}$ \\
\hline
\end{tabular}

Yu et al.: Metachronous Sigmoid Carcinoma and Mantle Cell Lymphoma in Intestines
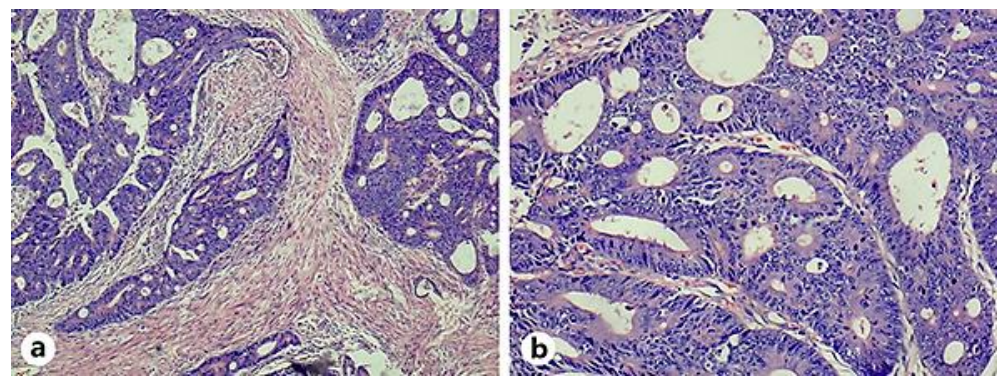

Fig. 1. Adenocarcinoma which is tubular, moderately differentiated, infiltrating into the deep muscle layer. a H\&E, magnification $\times 40$. b H\&E, magnification $\times 100$.

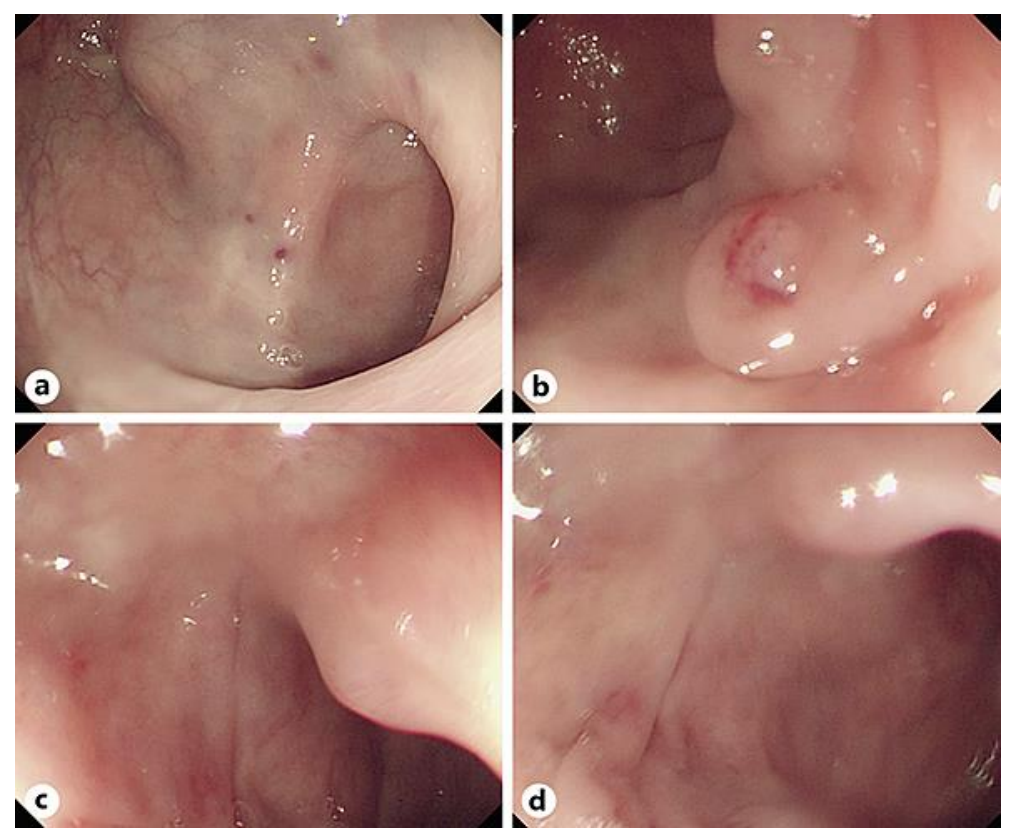

Fig. 2. Endoscopic image: anastomosis was found $20 \mathrm{~cm}$ away from the anus edge, and the mucosa of the anastomosis was smooth, with no erosion, ulcer or tumor (a). Three polypoid growths were seen $45 \mathrm{~cm}$ away from the anal margin (b-d), with a size of about $0.2 \mathrm{~cm} \times 0.2 \mathrm{~cm}$ to $0.4 \mathrm{~cm} \times 0.4 \mathrm{~cm}$, and one polyp surface was flushed (b). 


\section{Case Reports in Gastroenterology}
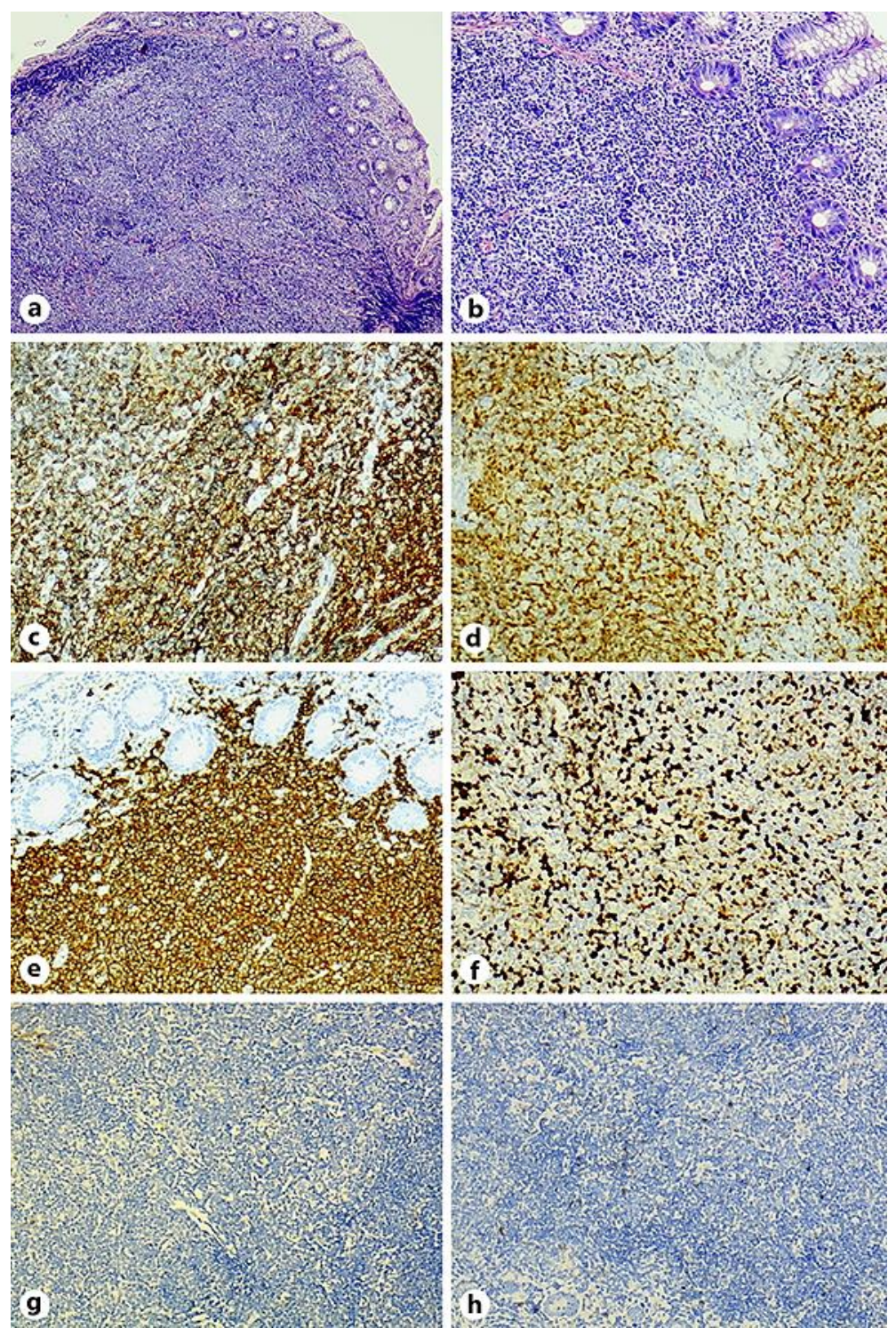

Fig. 3. A large number of lymphoid tissue hyperplasia under the mucosa of sigmoid colon, with a single morphology. a H\&E, magnification $\times 40$. b H\&E, magnification $\times 100$. c CD5, magnification $\times 100$. d cyclin D1, magnification $\times 100$. e CD20, magnification $\times 100$. $\mathbf{f}$ Ki-67, magnification $\times 100$. $\mathbf{g}$ CD10, magnification $\times 100$. h CD23, magnification $\times 100$. 


\section{Case Reports in Gastroenterology}

\begin{tabular}{l|l}
\hline Case Rep Gastroenterol 2019;13:17-24 \\
\hline DOI: 10.1159/000495781 & $\begin{array}{l}\text { @ 2019 The Author(s). Published by S. Karger AG, Basel } \\
\text { www.karger.com/crg }\end{array}$ \\
\hline
\end{tabular}

Yu et al.: Metachronous Sigmoid Carcinoma and Mantle Cell Lymphoma in Intestines

Table 1. Simultaneous or metachronous colon carcinoma and MCL of colon reported in the literature

\begin{tabular}{|c|c|c|c|c|c|c|c|}
\hline Author & $\begin{array}{l}\text { Publication } \\
\text { year/ } \\
\text { country }\end{array}$ & $\begin{array}{l}\text { Age/ } \\
\text { Sex }\end{array}$ & Site of intestinal cancer/ MCL & TDMRC & IHC & $\begin{array}{l}\text { Stage } \\
\text { of MCL }\end{array}$ & $\begin{array}{l}\text { Follow-up } \\
\text { status }\end{array}$ \\
\hline $\begin{array}{l}\text { Handra-Luca } \\
{[16]}\end{array}$ & $\begin{array}{l}2013 / \\
\text { France }\end{array}$ & $\begin{array}{l}80 / \\
\mathrm{M}\end{array}$ & colorectum/colorectum & synchronous & $\begin{array}{l}\text { CD20 (+), CD5 }(+), \text { bcl2 }(+), \text { cyclin } \\
\text { D1 }(+)\end{array}$ & IV & NA \\
\hline $\begin{array}{l}\text { Liao et al. } \\
{[18]}\end{array}$ & $\begin{array}{l}2009 / \\
\text { China }\end{array}$ & $\begin{array}{l}75 / \\
M\end{array}$ & sigmoid/duodenum & $\begin{array}{l}20 \text { months after } \\
\text { chemoradiotherapy }\end{array}$ & $\begin{array}{l}\text { CD5 }(+), \operatorname{CD} 20(+), \operatorname{CD} 45(+), \text { cyclin } \\
\text { D1 }(+)\end{array}$ & IV & $\begin{array}{l}\text { died of profound multi- } \\
\text { ple organ dysfunction } \\
\text { syndromes in February } \\
2005\end{array}$ \\
\hline $\begin{array}{l}\text { Sztarkier et al. } \\
{[17]}\end{array}$ & $\begin{array}{l}2009 / \text { Is- } \\
\text { rael }\end{array}$ & $\begin{array}{l}80 / \\
M\end{array}$ & $\begin{array}{l}\text { sigmoid colon/bone marrow, } \\
\text { colon and then massive }\end{array}$ & 6 months later & CD20(+), cyclin D1(+), CD43(+) & NA & $\begin{array}{l}\text { died } 14 \text { months after the } \\
\text { original colectomy }\end{array}$ \\
\hline $\begin{array}{l}\text { Padmanabhan } \\
\text { and Trainer [15] }\end{array}$ & $\begin{array}{l}2003 / \\
\text { USA }\end{array}$ & $\begin{array}{l}83 / \\
M\end{array}$ & $\begin{array}{l}\text { cecum, colon, and terminal } \\
\text { ileum with involvement of the } \\
\text { regional lymph nodes/same as } \\
\text { intestinal cancer }\end{array}$ & synchronous & $\begin{array}{l}\text { CD20(+), cyclin D1 }(+), \text { CD5 }(+), \\
\text { BCL-2 (+), } \kappa \text { light chain }(+), \text { CD3 }(- \\
\text { ), CD10 }(-) .\end{array}$ & NA & $\begin{array}{l}\text { died of many causes af- } \\
\text { ter a month }\end{array}$ \\
\hline $\begin{array}{l}\text { Kanehira et al. } \\
{[14]}\end{array}$ & $\begin{array}{l}2001 / \\
\text { USA }\end{array}$ & $\begin{array}{l}54 / \\
M\end{array}$ & hepatic flexure/ileum & synchronous & $\begin{array}{l}\text { CD20(+), CD5(+), cyclin D1 (+), } \\
\text { CD10(-), CD23(-) }\end{array}$ & NA & $\begin{array}{l}\text { alive and well } 6 \text { months } \\
\text { after surgery }\end{array}$ \\
\hline $\begin{array}{l}\text { Kanehira et al. } \\
{[14]}\end{array}$ & $\begin{array}{l}2001 / \\
\text { USA }\end{array}$ & $\begin{array}{l}74 / \\
M\end{array}$ & rectum/colon and lymph node & synchronous & $\begin{array}{l}\text { CD20 (+), CD5(+), cyclin D1 (+), } \\
\operatorname{CD} 10(-), \operatorname{CD} 23(-)\end{array}$ & NA & $\begin{array}{l}\text { alive and well for } 4 \\
\text { months after surgery }\end{array}$ \\
\hline This study & $\begin{array}{l}\text { 1018/ } \\
\text { China }\end{array}$ & $\begin{array}{l}69 / \\
M\end{array}$ & $\begin{array}{l}\text { sigmoid/sigmoid, TRANSVERSE } \\
\text { colon }\end{array}$ & 7 years later & $\begin{array}{l}\mathrm{CD} 20(+), \operatorname{CD} 79 \alpha(+), \mathrm{CD} 5(+), \mathrm{Cy}- \\
\text { clin D1(+), CD43(+), Bcl-2(+), } \\
\text { CD21(+), CD23(-), CD10(-), Ki-67 } \\
(40 \%)\end{array}$ & I & $\begin{array}{l}\text { alive and well for } 13 \\
\text { months after suffering } \\
\text { MCL }\end{array}$ \\
\hline
\end{tabular}

DTMRC, the diagnosis time of MCL related to intestinal cancer; M, male; NA, not available. 